\title{
Oxidative status in Medicago truncatula Gaertn. non-embryogenic and embryogenic tissues with particular reference to somatic embryogenesis
}

\author{
Anna Orłowska ${ }^{1} \cdot$ Ewa Kępczyńska $^{1}$
}

Received: 19 June 2019 / Accepted: 1 October 2019 / Published online: 9 October 2019

(c) The Author(s) 2019

\begin{abstract}
Abiotic stress conditions (e.g., wounding, sterilization) are often together with plant growth regulators (e.g., 2,4-D), considered as one of the most important factors initiating plant somatic embryogenesis (SE). The first goal of this work was to answer whether leaf explants of the Medicago truncatula non-embryogenic (M9) line and its embryogenic variant (M9-10a) respond equally to mechanical and chemical stress by analyzing ROS (reactive oxygen species, e.g., $\mathrm{O}_{2}^{\bullet-}, \mathrm{H}_{2} \mathrm{O}_{2}$ ) localization, ROS scavenging enzyme activity and expression of genes encoding these enzymes. In explants of both lines, the stress response induced by wounding and chemical sterilization and the defense reaction during the 1st week of callus growth was similar. These defense mechanisms first involve an increase in SOD and CAT activity, later APX. 2,4-D, present at a low concentration $(0.5 \mu \mathrm{M})$ during the induction phase (IP), is necessary for embryogenic callus formation and, consequently, for embryo development. This herbicide in higher concentrations causes an increase in $\mathrm{O}_{2}^{--}$accumulation and in antioxidant enzyme activity; however, it does not block the formation of callus and somatic embryos, though it disturbs these processes. Moreover, inhibition or blocking studied processes by DPI, an inhibitor of NADPH oxidase responsible for the production of $\mathrm{O}_{2}^{--}$and also lowering the expression of genes encoding the antioxidant enzymes leading to change in their activities, clearly indicate that a certain level of ROS is necessary to induce SE.
\end{abstract}

\section{Key message}

During somatic embryogenesis of Medicago truncatula stress does not affect the acquisition of embryogenic competence, but certain level of ROS and 2,4-D are necessary to induce this process.

Keywords Somatic embryogenesis $\cdot$ Fabaceae $\cdot$ Oxidative stress $\cdot$ ROS $\cdot$ 2,4-D $\cdot$ DPI

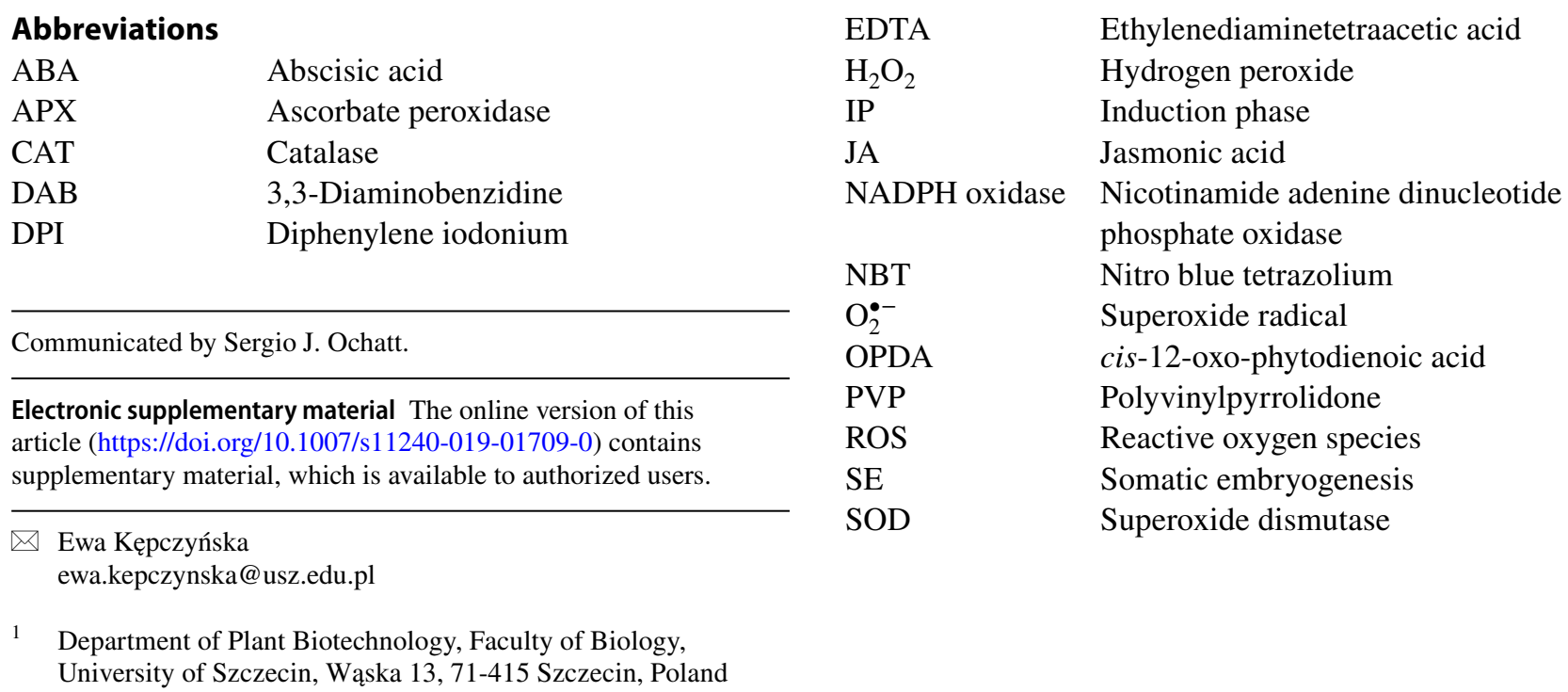




\section{Introduction}

Plant cells have the unique ability to change their developmental program from vegetative to embryonic in a multistep process known as a somatic embryogenesis (SE). During embryogenesis, the somatic cells of the explant must pass through four stages, of which the most important are induction and dedifferentiation. Each of these stages requires changes in plant cells on the genetic, epigenetic, proteomic and biochemical level, which results in their dedifferentiation to the meristemic state and then differentiation into somatic embryos (Zavattieri et al. 2010; Rose 2019). SE is one of the most investigated plant regeneration systems, but so far, the induction and regulation mechanisms have not been fully understood because of the complicated processes at the cellular level.

Many conditions influence the ability of somatic cells to dedifferentiation. Auxins and cytokinins are the key regulators of the division and differentiation of plant cells. These regulators are most often used to control organ regeneration, callus induction and somatic embryogenesis. Together, they stimulate the processes of dedifferentiation and reprogramming of somatic cells (Rose et al. 2013). The most commonly used inducer is an herbicide with the properties of auxin in the form of 2,4-dichlorophenoxyacetic acid (2,4-D). In low concentrations, it stimulates plant growth, while in high concentrations it acts as an herbicide that interferes with normal functioning and causes damage, which in turn can lead to death (Grossmann 2010). Therefore, 2,4-D acts simultaneously as a plant growth regulator and a herbicide that causes stress in cells (Fehér 2015). 2,4-D also induces the acquisition of competence for embryogenesis by plant cells. In SE, it can act as an auxin or modify the intracellular indolylacetic acid (IAA) metabolism. It can also act as a stress factor leading to an aerobic explosion in the cells (Karami and Saidi 2010). 2,4-D increases the production of superoxide radical $\left(\mathrm{O}_{2}^{--}\right)$and hydrogen peroxide $\left(\mathrm{H}_{2} \mathrm{O}_{2}\right)$ in Pisum sativum seedlings (Romero-Puertas et al. 2004) and Vigna radiata leaves (Karuppanapandian et al. 2011). Numerous studies have shown that stress promotes cell dedifferentiation and also may induce the formation of somatic embryos (Zavattieri et al. 2010; Elhiti and Stasolla 2015).

In addition, the number of external stresses needs to be considered in the context of SE regulation. Regeneration procedure starts with detachment of explant from mother plant (wounding stress), subject it to surface sterilization (oxidative stress) and put it on artificial medium (dehydratation/osmotic stress) (Nolan et al. 2006). The consequence of the above-mentioned stresses is, among others, an increase in the production of reactive oxygen species (ROS), including such reactive oxidants as $\mathrm{O}_{2}^{\cdot-}, \mathrm{H}_{2} \mathrm{O}_{2}$ and others. One of the main sources of ROS formed in cells as a result of stress factors is the nicotinamide adenine dinucleotide phosphate oxidase (NADPH oxidase). NADPH oxidase produces $\mathrm{O}_{2}^{\bullet-}$, which spontaneously or as a result of superoxide dismutase (SOD) dissociates into $\mathrm{H}_{2} \mathrm{O}_{2}$. The $\mathrm{H}_{2} \mathrm{O}_{2}$ is then transformed into $\mathrm{H}_{2} \mathrm{O}$ as a result of such activities as catalase (CAT) activity and ascorbate peroxidase (APX) activity. Earlier, we showed that the subjection of Medicago sativa tissue to mechanical and chemical treatments during the initial steps of SE resulted in a rapid and high accumulation of stress-related hormones, i.e. abscisic acid (ABA), jasmonic acid (JA) and JA precursor, cis-12-oxo-phytodienoic acid (OPDA), but did not alter the endogenous auxin level (IAA; Ruduś et al. 2009). The increase in ABA, JA and OPDA contents in initial explants is apparently the first signal for developmental changes such as cell division and the establishment of embryogenic competence, which can be triggered by cellular stresses (Pasternak et al. 2007). Increasing evidence suggests that ROS might function as a signal molecule transducing external stimuli into cellular responses and the involvement these ROS in various hormone-dependent developmental processes (Pasternak et al. 2007). In addition, competence to the induction of SE is highly correlated with the genotype, as exemplified by two Medicago truncatula Gaertn. embryogenic variants; 2HA and M9-10a (Nolan et al.1989; Neves et al. 1999), which are considered as model for the study of SE in species. Both lines were derived from non-embryogenic genotypes A17 and M9 respectively, which makes possible to compare when SE is "switched on" or "switched off". To date, there is has been no data concerning the comparison of oxidative status in tissues of the non-embryogenic and embryogenic lines subjected to mechanical and chemical stresses.

Therefore the aim of the present study was to compare (i) accumulation of $\mathrm{O}_{2}^{\bullet-}$ and $\mathrm{H}_{2} \mathrm{O}_{2}$ in primary explants of the non-embryogenic (M9) and embryogenic (M9-10a) lines of $M$. truncatula $\mathrm{cv}$. Jemalong after mechanical and chemical stresses, (ii) the activity of antioxidant enzymes (SOD, CAT, APX) responsible for utilization of the above ROS, and (iii) the expression of genes encoding antioxidant enzymes during the 1 st week of the induction phase (IP). Moreover, we checked if manipulation of the $\mathrm{O}_{2}^{\bullet-}$ level by 2,4-D and the NADPH oxidase inhibitor, DPI, have influence on callus formation and somatic embryo production, and on the activity of antioxidant enzymes and the expression of genes encoding them during the 1st week of the IP of somatic embryogenesis. 


\section{Materials and methods}

\section{Tissue culture protocol}

Tissue culture was conducted using the M. truncatula $\mathrm{cv}$. Gaertn. non-embryogenic (M9) and embryogenic (M9-10a) line according to the protocol described previously (Orłowska et al. 2017). For donor plant production, we used seeds of the above mentioned lines, kindly provided by Professor Pedro Manuel Fevereiro, ITQB, Portugal (Neves et al. 1999). Primary leaf explants were placed on standard SH (Schenk and Hildebrandt 1972) medium supplemented with $0.5 \mu \mathrm{M} 2,4-\mathrm{D}$ and $1 \mu \mathrm{M}$ zeatin or SH medium supplemented with $1 \mu \mathrm{M}$ zeatin and 2,4-D in concentrations of $0,1,5,20$, $50 \mu \mathrm{M}$ or DPI in concentrations $1,10,100 \mu \mathrm{M}$ and $0.5 \mu \mathrm{M}$ 2,4-D. Subsequently, the callus tissue was transferred to the MS differentiation medium (Murashige and Skoog 1962) for 14 days.

\section{In situ localization of $\mathrm{O}_{2}^{--}$and $\mathrm{H}_{2} \mathrm{O}_{2}$}

Localization of $\mathrm{O}_{2}^{--}$and $\mathrm{H}_{2} \mathrm{O}_{2}$ was determinate on leaf explants of the M. truncatula M9 and M9-10a lines after chemical (leaf explants were placed in $1 \%$ sodium hypochlorite for $3 \mathrm{~min}$, then rinsed three times in sterile distilled water) and mechanical (leaf explants, not treated with sodium hypochlorite, were cut with a sterile scalpel into squares with a side length of $1 \mathrm{~cm}$ and cut across the midrib) stress treatments. The experiment was carried out in five independent biological replicates and each of them consisted of three trifoliate leaf explants (technical replicates). After $1 \mathrm{~min}$ from applying the stress factor, leaf explants were placed in a staining solution or transferred to standard $\mathrm{SH}$ medium for 1 day and after this time $\mathrm{O}_{2}^{\bullet-}$ and $\mathrm{H}_{2} \mathrm{O}_{2}$ were stained in the tissue. The in situ location of $\mathrm{O}_{2}^{\circ-}$ and $\mathrm{H}_{2} \mathrm{O}_{2}$ was also determined in M9-10a tissues collected immediately from mother plants and after 2, 7, 14, 21 day of the SE induction phase cultured on medium containing $5 \mu \mathrm{M} 2,4-\mathrm{D}$ or $10 \mu \mathrm{M}$ DPI. To obtain clear staining results, chlorophyll was removed from explants by boiling in a solution of $96 \%$ ethanol, $99.5 \%$ acetic acid and glycerol (v/v/v, 3:1:1) for $30 \mathrm{~min}$ at $90^{\circ} \mathrm{C}$ in a water bath.

In situ localization of $\mathrm{O}_{2}^{\bullet-}$ was carried out after staining explants in a solution of $6 \mathrm{mM}$ nitro blue tetrazolium (NBT) in $10 \mathrm{mM}$ Tris- $\mathrm{HCl}\left(\mathrm{pH} \mathrm{7.4)}\right.$ for $10 \mathrm{~min}$ at $25^{\circ} \mathrm{C}$ in the dark. Pale yellow NBT reacts with $\mathrm{O}_{2}^{--}$to form dark blue insoluble formazan (Fryer et al. 2002). For detection of $\mathrm{H}_{2} \mathrm{O}_{2}$, explants were stained in a $5 \mathrm{mM} \mathrm{3,3-diaminobenzidine} \mathrm{(DAB)} \mathrm{in}$ $10 \mathrm{mM} \mathrm{Na} \mathrm{HPO}_{4}$ and $0.05 \%$ Tween-20 for $90 \mathrm{~min}$ at $25^{\circ} \mathrm{C}$ in the dark. The controls were explants incubated in $10 \mathrm{mM}$ $\mathrm{Na}_{2} \mathrm{HPO}_{4}$ and $0.05 \%$ Tween-20 in these same conditions.
DAB reacts with hydrogen peroxide to form a brown polymerization product (Thordal-Christensen et al. 1997).

\section{Antioxidant enzyme activity determination}

To determine the activity of superoxide dismutase (SOD), catalase (CAT) and ascorbate peroxidase (APX), leaf explants of the M. truncatula M9 and M9-10a line were collected at $0,1,3,5,7$ days of the IP incubated on induction medium supplemented with $1 \mu \mathrm{M}$ of zeatin and one of the following compounds: $0.5 \mu \mathrm{M}$ 2,4-D (M9 and M9-10a); $5 \mu \mathrm{M}$ 2,4-D (M9-10a) or $10 \mu \mathrm{M}$ DPI $+0.5 \mu \mathrm{M}$ 2,4-D (M9-10a). Five independent biological replicates were obtained per a time point and each of biological replicates consisted of five trifoliate leaf explants cultivated on independent Petri dishes.

Antioxidant enzymes were isolated from $100 \mathrm{mg}$ frozen tissue. To determine the activity of SOD, tissue was homogenized in $4 \mathrm{ml}$ of extraction buffer containing $0.1 \mathrm{M}$ sodium phosphate buffer ( $\mathrm{pH} 7.8$ ), $1 \mathrm{mM}$ ethylenediaminetetraacetic acid (EDTA) and $2 \%$ polyvinylpyrrolidone (PVP). To determine CAT and APX, activity tissue was homogenated in $1.5 \mathrm{ml}$ extraction buffer containing $0.1 \mathrm{M}$ sodium phosphate buffer (pH 7.0), 1 mM EDTA and 1\% PVP. All homogenates were centrifuged at $15,000 \times g$ for $20 \mathrm{~min}$ at $4{ }^{\circ} \mathrm{C}$. The supernatants were collected and used for further analysis. Total proteins were determined according to the Bradford (1976) method.

The SOD activity was determined using a reaction solution containing $0.1 \mathrm{M}$ sodium phosphate buffer $(\mathrm{pH}$ 7.8), $13 \mathrm{mM}$ methionine, $0.1 \mathrm{mM}$ EDTA, $63 \mu \mathrm{M}$ NBT and $1.3 \mu \mathrm{M}$ riboflavin and $0.1 \mathrm{ml}$ plant extract (Giannopolitis and Ries 1977). The samples were illuminated for $45 \mathrm{~min}$ under $50 \mu \mathrm{M} \mathrm{m}^{-2} \mathrm{~s}^{-1}$ at $25^{\circ} \mathrm{C}$. The control was a reaction solution without the samples, which was illuminated in the same conditions. The blank solution was kept in the dark. The ability of SOD to inhibit the photoreduction of NBT by $50 \%$ was monitored at $560 \mathrm{~nm}$.

To determine CAT activity, we used the protocol described by Aebi (1974). CAT activity was monitored for $1 \mathrm{~min}$ at $240 \mathrm{~nm}$ and evaluated by the degradation of $\mathrm{H}_{2} \mathrm{O}_{2}$ in a reaction solution containing $10 \mathrm{mM}$ sodium phosphate buffer ( $\mathrm{pH} 7.0$ ), $0.036 \% \mathrm{H}_{2} \mathrm{O}_{2}$ and $300 \mathrm{ml}$ plant extract. The blank solution was $10 \mathrm{mM}$ sodium phosphate buffer ( $\mathrm{pH} 7.0)$ and $0.036 \% \mathrm{H}_{2} \mathrm{O}_{2}$.

The APX activity was determined according to the method of Nakano and Asada (1981). The oxidation rate of ascorbate by APX was measured at $290 \mathrm{~nm}$ for $1 \mathrm{~min}$. The reaction solution containing $0.1 \mathrm{M}$ sodium phosphate buffer ( $\mathrm{pH} 7.0), 5 \mathrm{mM}$ sodium ascorbate and $0.2 \mathrm{ml}$ plant extract was incubated for $5 \mathrm{~min}$ at $35^{\circ} \mathrm{C}$. After this time $1 \mathrm{mM} \mathrm{H}_{2} \mathrm{O}_{2}$ was added and the oxidation rate of ascorbate by APX was measured at $290 \mathrm{~nm}$ for $1 \mathrm{~min}$. The blank 
solution contained $0.1 \mathrm{M}$ sodium phosphate buffer $(\mathrm{pH}$ 7.0) and $5 \mathrm{mM}$ sodium ascorbate. The activity of SOD, $\mathrm{CAT}$ and APX were expressed in nkat $\mathrm{mg}^{-1}$ protein.

\section{Protein alignment and phylogenetic analysis}

The amino acid sequences of APX proteins from the Arabidopsis thaliana database (https://www.arabidopsi s.org/) were used as queries to perform a BLASTp search against the $M$. truncatula genome (http://www.medic agogenome.org/) and NCBI databases. The homology of full-length protein sequences was checked by sequence alignment analysis using the ClustalW function of the Geneious 6.1 software (http://www.geneious.com, Kearse et al. 2012). The phylogenetic trees were based on the Neighbor-Joining method with the bootstrap parameter was set to 1000 .

\section{Gene expression analysis}

Total RNA was extracted from the plant material at 0,1 , 3, 5 and 7 days of the IP incubated on induction medium supplemented with $1 \mu \mathrm{M}$ of zeatin and one of the following compounds: $0.5 \mu \mathrm{M}$ 2,4-D (M9 and M9-10a); $5 \mu \mathrm{M}$ 2,4D (M9-10a) and $10 \mu \mathrm{M}$ DPI $+0.5 \mu \mathrm{M}$ 2,4-D (M9-10a) as described previously (Orłowska and Kępczyńska 2018). Primer sequences of genes encoding SOD, CAT and APX for $\mathrm{qPCR}$ are listed in Table 1. All the experiments were carried out in triplicate. The results are expressed as mean \pm SD. Statistical analyses were performed using ANOVA followed by Tukey's HSD post hoc test. Differences between the mean values were considered to be significant at $\mathrm{p}<0.01$ or $\mathrm{p}<0.05$.

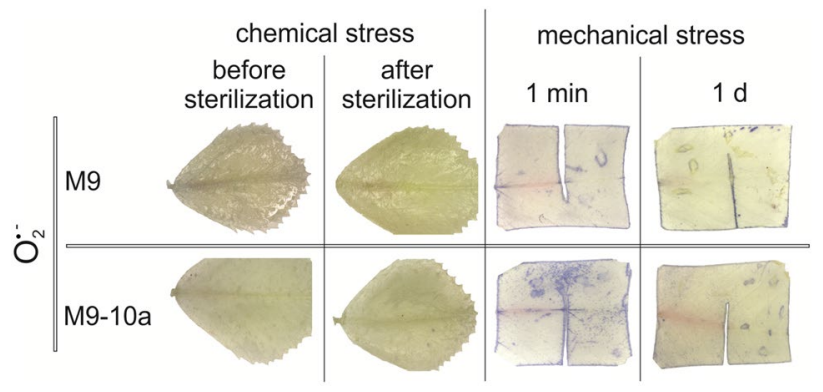

Fig. 1 In situ location of $\mathrm{O}_{2}^{\bullet-}$ in primary leaf explants of non-embryogenic (M9) and embryogenic (M9-10a) lines of Medicago truncatula after chemical and mechanical stress
Table 1 Description of the analyzed genes and their primer sequences

\begin{tabular}{llll}
\hline Gene name short & $\begin{array}{l}\text { Accession number } \\
\text { nucleotide/protein }\end{array}$ & Gene symbol & Primer sequence \\
\hline CuZnSOD1 & XM_003606280.2 & MTR_4g057240 & F: CTCCAGGGCTTCATGGTTTTC \\
& XP_003606328.2 & & R: CCGTGTGTCAACTGGTTAGGATT \\
CuZnSOD3 & XM_003618899.2 & MTR_6g029200 & F: ACCACCAATGGCTGCAACTC \\
& XP_003618947.1 & & R: TACCCAAATCACCGGCATGT \\
CuZnSOD4 & XM_003626314.2 & MTR_7g114240 & F: TGAGACTCGACATGCTGGTG \\
& XP_003626362.1 & & R: TTTGGTCCGGTGAGAGGGAT \\
FeSOD1 & XM_013611853.1 & MTR_1g048990 & F: ATGCTGTGAACCCCCTTGTTT \\
& XP_013467307.1 & & R: TCAGGACGCCGATTCTGATAG \\
FeSOD2 & XM_013605625.1 & MTR_3g078860 & F: GGGAGAGCATCATCGGAATTT \\
MnSOD & XP_013461079.1 & & R: TGTCACTTTGACCAGTTCATCCA \\
& XM_013606079.1 & MTR_3g094250 & F: GTTCAACGGTGGAGGTCATATCA \\
CAT1 & XP_013461533.1 & & R: CCATCCCAGGGCTTCCTTT \\
& XM_013606823.1 & MTR_3g115370 & F: CGCACCTGACTTGTGCAGATT \\
APX1 & XP_013462277.1 & & R: GTTTCAGGGCTACCACGTTCA \\
& XM_003606462.2 & MTR_4g061140 & F: GCATGGCACTCTGCTGGAA \\
APX3 & XP_003606510.1 & & R: CGTTGTTAGCACCATGAGCAA \\
& XM_003607151.2 & MTR_4g073410 & F: TCTCATCGCCAACAGAAACTGT \\
APX5 & XP_003607199.1 & & R: AGCATTAGGTCCACCGGTCTT \\
APX6 & XM_003612157.2 & MTR_5g022510 & F: AGCTGAACCATGCTGCTAACAA \\
& XP_003612205.2 & & R: TGGTAAAGGTCCGCATATGAAA \\
& XM_003603341.2 & MTR_3g107060 & F: TTGTCTGGAGCCCACACTCTT \\
& XP_003603389.1 & & R: AAGGCGTCCATGGCTTCTC \\
\hline
\end{tabular}




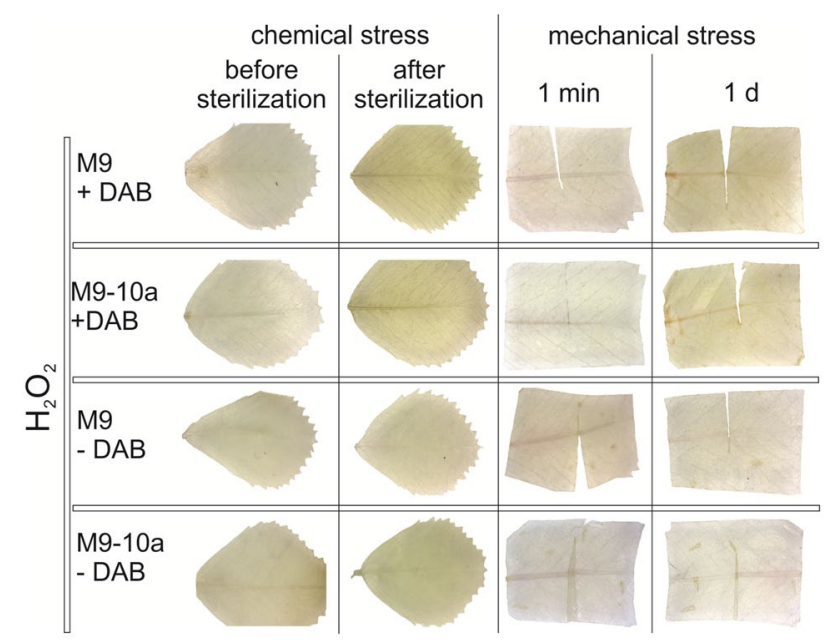

Fig. 2 In situ location of $\mathrm{H}_{2} \mathrm{O}_{2}$ in primary leaf explants of the nonembryogenic (M9) and embryogenic (M9-10a) lines of Medicago truncatula after the chemical and mechanical stress

\section{Results}

\section{Accumulation of $\mathrm{O}_{2}^{--}$and $\mathrm{H}_{2} \mathrm{O}_{2}$ in primary explants of non-embryogenic and embryogenic lines of M. truncatula under the influence of chemical and mechanical stress}

Insoluble blue formazan precipitates did not appear on leaf explants of either tested line in response to sodium hypochlorite (chemical stress; Fig. 1), indicating the lack of accumulation of $\mathrm{O}_{2}^{\bullet-}$. However, after mechanical stress treatment, blue formazan crystals were visible at the tissue wounding sites. Formazan appeared just $1 \mathrm{~min}$ after the incision, covering all the damaged areas of the explants of both lines, and was also detected on the 1st day of induction. In contrast to $\mathrm{O}_{2}^{--}, \mathrm{H}_{2} \mathrm{O}_{2}$ accumulation was observed in the $\mathrm{M} 9$ and M9-10a tissue after both chemical and mechanical stress (Fig. 2). Sterilization of explants with sodium hypochlorite induced an accumulation of hydrogen peroxide, visible as a brown color, along the midrib in the explants of both analyzed $M$. truncatula lines. After mechanical damage in the midrib of both line explants, $\mathrm{H}_{2} \mathrm{O}_{2}$ was observed only on the 1 st day of IP. Thus the response to chemical and mechanical stress in tissue of both lines was the same.

\section{The activity of antioxidant enzymes and the expression of its encoding genes during the IP}

In response to abiotic stresses, accumulation of $\mathrm{O}_{2}^{--}$and $\mathrm{H}_{2} \mathrm{O}_{2}$ was found to be similar in the tissues of both lines, so it was interesting to check the enzyme superoxide dismutase (SOD), catalase (CAT) and ascorbate peroxidase (APX)
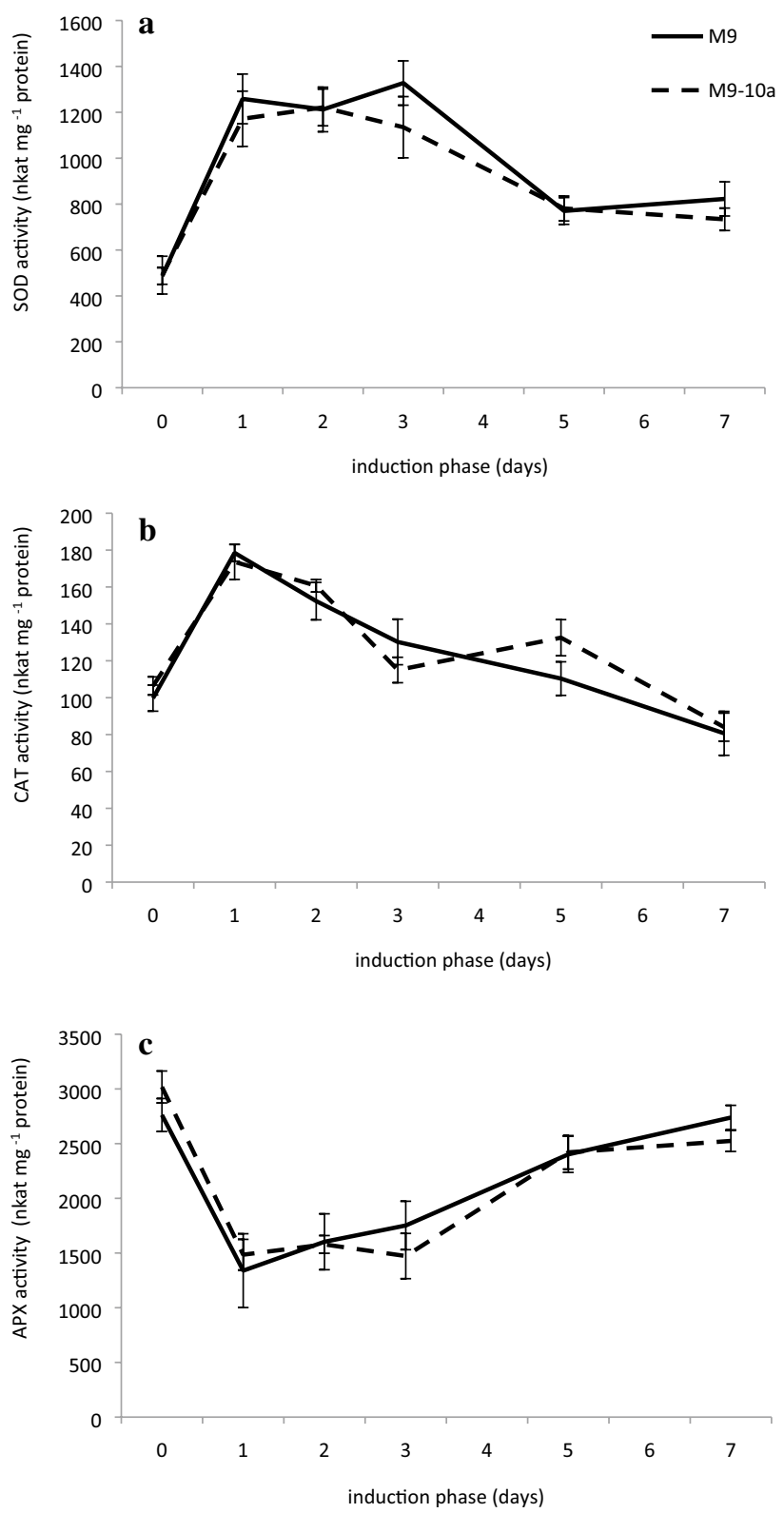

Fig. 3 Superoxide dismutase (SOD, a), catalase (CAT, b) and ascorbate peroxidase (APX, c) activity during the induction phase (7 days) in the non-embryogenic (M9) and embryogenic (M9-10a) line of Medicago truncatula. Statistical analyses, ANOVA with confidence interval 0.05, significance between groups indicated as * for $\mathrm{P} \leq 0.05$, $* *$ for $\mathrm{P} \leq 0.01, * * *$ for $\mathrm{P} \leq 0.001$ and $* * * *$ for $\mathrm{P} \leq 0.0001$. Bars indicate \pm SD

activity and the expression of the genes encoding these antioxidant proteins during the 1 st week of the IP, because in this period key changes in the expression of genes occur.

On the 1st day of the IP in the explants of both lines, a rapid increase (twofold) of SOD activity was observed (Fig. 3a), which remained at a similar level to the 3rd day in the explants of both lines. After this, there was a decrease in enzyme activity, which showed a constant value from the 


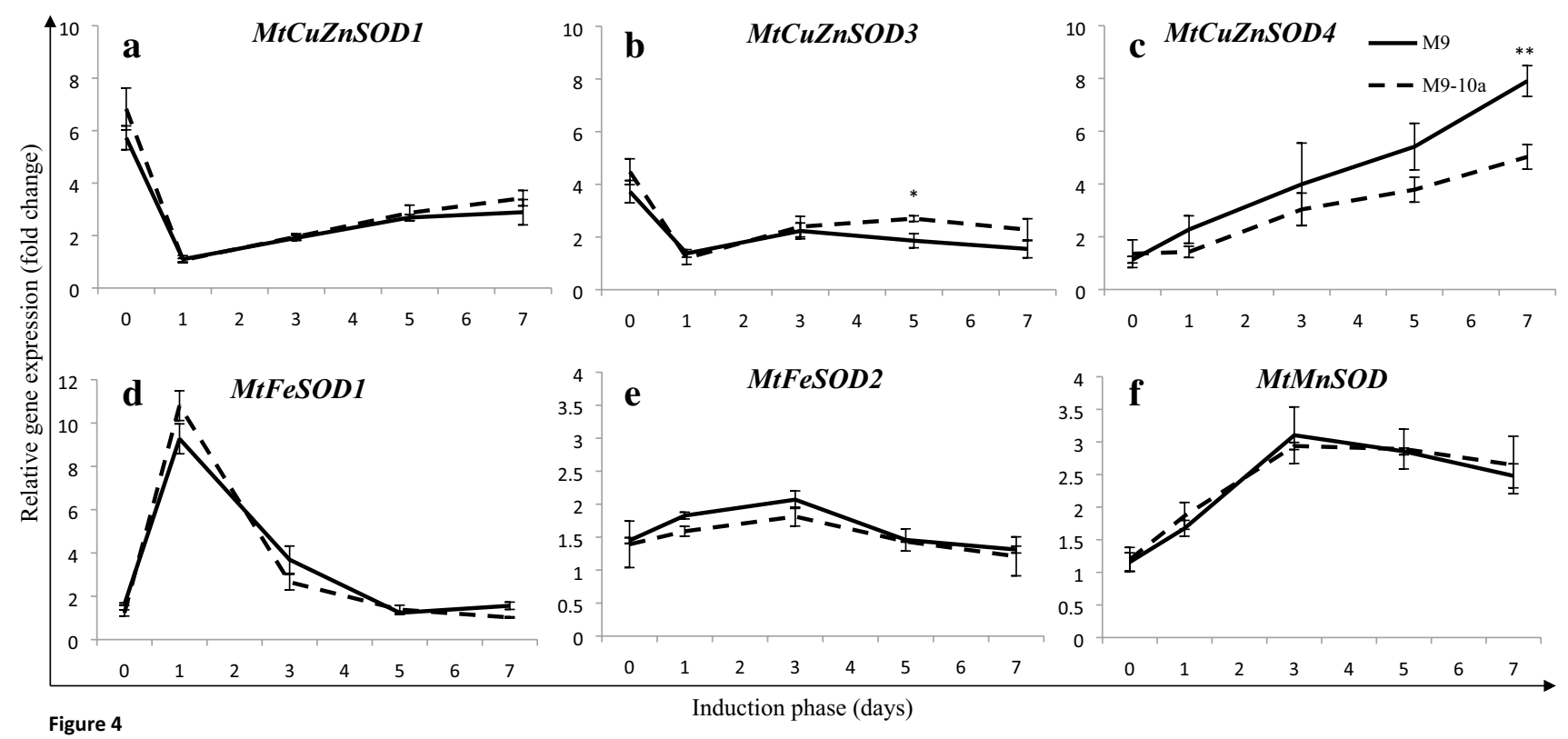

Fig. 4 Timecourse study of MtCuZnSOD1 (a), MtCuZnSOD3 (b), MtCuZnSOD4 (c), MtFeSOD1 (d), MtFeSOD2 (e) and MtMnSOD (f) expression in the non-embryogenic (M9) line of Medicago truncatula and its embryogenic variant (M9-10a) during the induction phase ( 7 days) on a standard medium. Gene expression was normal-

5 th to 7 th day. There were no significant differences in SOD activity between both lines. At the same time, the expression of genes, earlier identified in the M. truncatula genome (Song et al. 2018), encoding SOD were also analyzed. Of the three genes encoding copper-zinc superoxide dismutase, only $\mathrm{CuZnSOD} 4$ was characterized by a gradual increase in the level of transcription from the 1st day of induction in both analyzed lines (Fig. 4c). On the 7th day, the expression of this gene was eight and fivefold higher compared with its expression in the primary explants in the M9 and M9-10a lines, respectively. A completely different expression dynamic in leaf explants of both lines had two other CuZnSOD genes (Fig. 4a, b). Until the 1st day of the IP, the transcription decreased, about sixfold for $\mathrm{CuZnSOD1}$ (Fig. 4a) and about fourfold for CuZnSOD3 (Fig. 4b). In the following days, a slight increase in expression was observed, but it was still at a lower level than in the primary explants. Two genes encoding iron superoxide dismutase (FeSOD) were characterized by an expression dynamic other than that for the above-mentioned genes (Fig. 4d, e). The level of $\mathrm{FeSOD} 2$ transcription almost did not change during the 1st week of induction in either line (Fig. 4e). The expression of FeSODI increased about tenfold on the 1st day, then gradually decreased, reaching a similar level of transcription as in the primary explant on the 5th day (Fig. 4d). The last analyzed gene was manganese superoxide dismutase. The expression of $M n S O D$ increased gradually until the 3rd day ized to ACTIN2 and relative to the lowest observed transcription. Bars show standard deviation. Solid and dotted lines represent the M9 and M9-10a lines, respectively. Statistical analyses, ANOVA with confidence interval 0.05 , significance between groups indicated as $*$ for $\mathrm{P} \leq 0.05, * *$ for $\mathrm{P} \leq 0.01, * * *$ for $\mathrm{P} \leq 0.001$ and $* * * *$ for $\mathrm{P} \leq 0.0001$

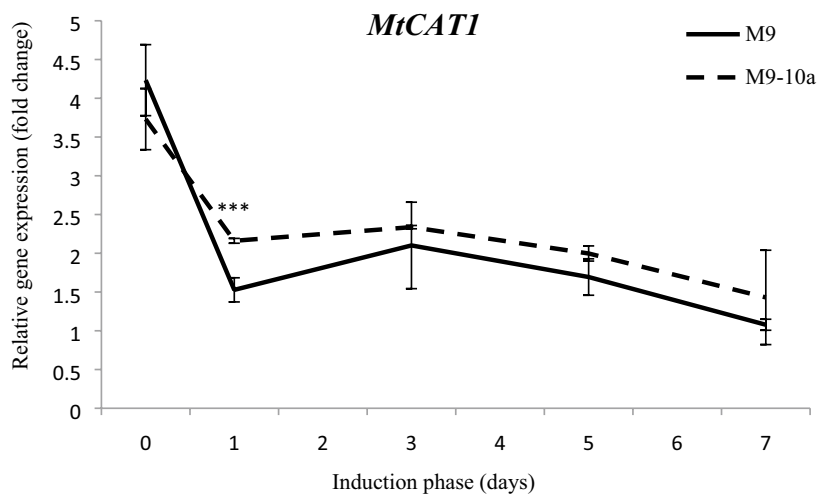

Fig. 5 Timecourse study of MtCAT1 expression in the non-embryogenic (M9) line of Medicago truncatula and its embryogenic variant (M9-10a) during the induction phase (7 days) on a standard medium. Gene expression was normalized to ACTIN2 and relative to the lowest observed transcription. Bars show standard deviation. Solid and dotted lines represent the M9 and M9-10a lines, respectively. Statistical analyses, ANOVA with confidence interval 0.05, significance between groups indicated as $*$ for $\mathrm{P} \leq 0.05$, ** for $\mathrm{P} \leq 0.01$, *** for $\mathrm{P} \leq 0.001$ and $* * * *$ for $\mathrm{P} \leq 0.0001$

(a threefold increase), then remained constant until the 7th day of the IP (Fig. 4f). Transcript level of genes encoding SOD did not show significant differences between both lines (except 5th day of CuZnSOD3 and 7th day of CuZnSOD4). 
Activity of $\mathrm{H}_{2} \mathrm{O}_{2}$ scavenger enzymes, CAT and APX, was also determined during the 1 st week of the IP. During the 1st day, a 1.5-fold increase in CAT activity was observed in both tested lines (Fig. 3b). In the following days, CAT activity gradually decreased, and on the 7th day, it was similar to that observed in the primary explants. Presently only one gene encoding CAT is known in the M. truncatula genome, CAT1 (Polidoros et al. 2003). Its expression in primary explants was the highest, then rapidly decreased about 2.5 -fold in the M9 line and 1.5-fold in the M9-10a line on the 1st day of induction (Fig. 5). In the following days, its transcription remained at a similar level in both tested lines of $M$. truncatula. The high expression of the CATI in primary explants does not coincided with the CAT activity. The rapid decrease in $C A T 1$ expression observed in subsequent days was accompanied by a gradual decrease in the activity of the enzyme (Fig. 4b) coded by this gene after the 1st day of the IP. There were no significant differences in CAT activity and expression of gene encoding it between both lines.

APX, the second enzyme, responsible for utilization of $\mathrm{H}_{2} \mathrm{O}_{2}$ was characterized by a different dynamic of activity compared with SOD and CAT during the IP (Fig. 3c). In contrast to these two, the activity of APX in primary explants was the highest and during the 1st day of the IP and rapidly decreased (about a twofold decrease, Fig. 3c). During later days, the activity gradually increased, and at the end of the 1st week of the IP, the activity reached a similar level to that of the primary explants. Next, before the APX gene expression experiment, sequence alignment analysis of the proteins encoded by these genes was carried

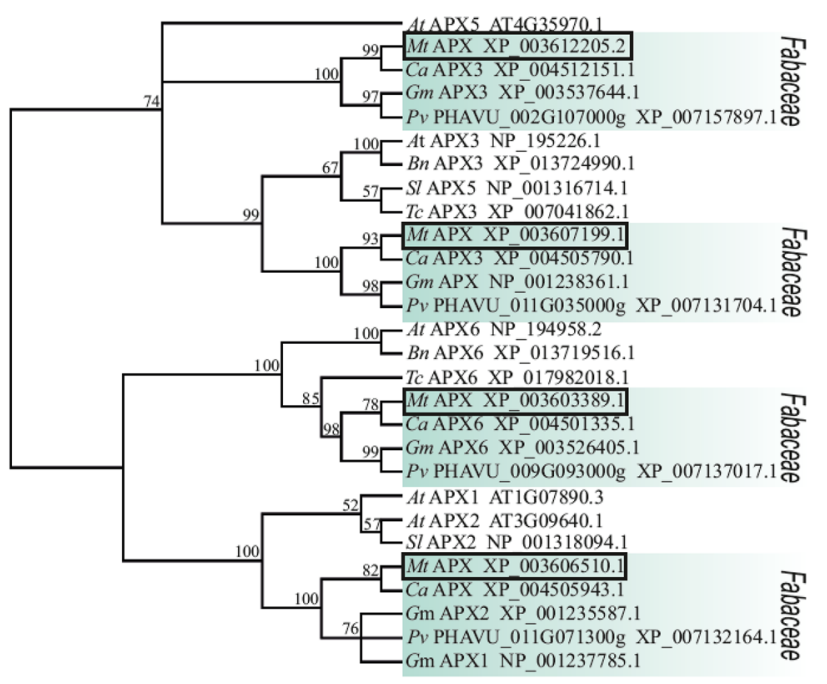

Fig. 6 Unrooted phylogenetic trees based on deduced amino acid sequences of Medicago truncatula ascorbate peroxidases (APX). At-Arabidopsis thaliana, Bn-Brassica napus, Ca-Cicer arietinum, Gm-Glycine max, Mt—Medicago truncatula, Pv—Phaseolus vulgaris, Sl-Solanum lycopersicum, Tc-Theobroma cacao out. Four ascorbate peroxidase proteins in M. truncatula were identified. These are APX1, APX3, APX5 and APX6, which separate into distinct clades (Fig. 6). Amino acid analysis showed that all the orthologous proteins found in the Fabaceae family belong to the same clades. M. truncatula APX1 is $81 \%$ identical to Arabidopsis thaliana APX1, while $M t$ APX 3 shows $78 \%$ similarity to AtAPX3. The $M$. truncatula APX5 and APX6 amino acid sequences are 66\% similar to the orthologous proteins found in A. thaliana. All identified genes were expressed during 7 days of the IP in both lines, but their expression profiles differed. Of the four genes encoding ascorbate peroxidase, only APXI showed a twofold increase in expression up to the 3rd day of induction in both $M$. truncatula lines and remained unchanged until the 7th day (Fig. 7a). Expression of the three remaining genes decreased during the 1st day of the IP, followed by an increase to the 3rd day (Fig. 7b-d). The APX3 and APX6 transcription levels did not change significantly between the 3rd and 7th days in either line. Between the fifth and 7th days, APX5 expression decreased in the M9-10a line, and was at a lower level than in the M9 line (Fig. 7c). There were no significant differences in APX activity and expression of genes encoding it between both lines (except 7th day of $A P X 5$ and 5th day of $A P X 6$ ).

Thus, the production of free radicals associated with chemical and mechanical stress is controlled during the 1st week of the IP by an efficient enzymatic antioxidant system; the genes encoding SOD, CAT and APX were expressed and as consequence, the expression translated into the activity of the enzymes encoded by these genes. During the 1st day, there was a very high increase in SOD and CAT activity, which gradually fell off to the 7th day. However, after the 1 st day, APX activity continued to grow up until 7 days, reaching the highest level of activity among the three enzymes tested.

\section{Effect of the presence of 2,4-D and DPI during IP on callus growth and embryo development}

Because ROS, as $\mathrm{O}_{2}^{--}$and $\mathrm{H}_{2} \mathrm{O}_{2}$, are present in explants during the 1st week of the SE induction phase, it was interesting to check if the herbicide 2,4-D, known for auxin-like properties, and DPI influenced the process of callus development and embryo formation. A lack of 2,4-D in the medium resulted in no formation of callus on leaf explants of the $M$. truncatula embryogenic line during the IP, thus no embryos were formed during the differentiation phase. The presence of 2,4-D at $0.5 \mu \mathrm{M}$ (standard medium) caused the development of light yellow callus characterized by a loose, granular structure. The entirety of the explants was overgrown with callus, which, after 14 days after transfer onto differentiating medium, was covered with embryos at various stages of development (Fig. 8). 2,4-D at $1 \mu \mathrm{M}$ caused a change 


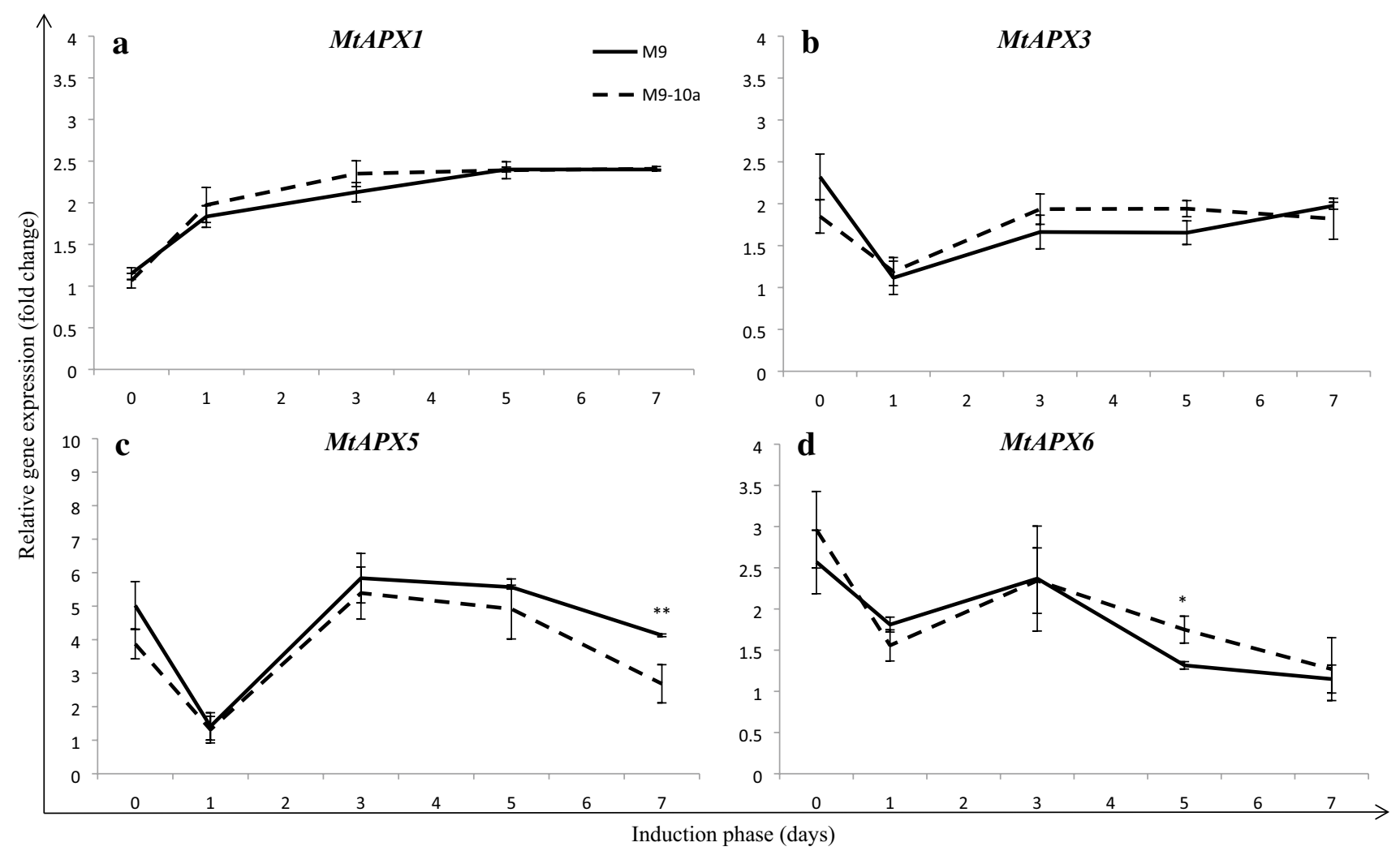

Fig. 7 Timecourse study of MtAPX1 (a), MtAPX3 (b), MtAPX5 (c) and MtAPX6 (d) expression in the non-embryogenic (M9) line of Medicago truncatula and its embryogenic variant (M9-10a) during the induction phase ( 7 days) on a standard medium. Gene expression was normalized to ACTIN2 and relative to the lowest observed

in callus color from light yellow to dark yellow, but did not affect the ability to form embryos on a differentiating medium. A tenfold increase in 2,4-D concentration $(5 \mu \mathrm{M})$ during the IP relative to its concentration in the standard medium caused callus to develop only at the cutting sites rather than on the entire surface of the explant. Moreover, its structure was looser compared with the standard medium; however, after 14 days, only embryos in the globular stage were observed on the differentiating medium. 2,4-D at even higher concentrations $(20 \mu \mathrm{M}$ and $50 \mu \mathrm{M})$ did not cause the inhibition of callus growth (Figs. 8 and 9), but it affected its structure. Either the callus was loose $(20 \mu \mathrm{M})$ or compacted and hard $(50 \mu \mathrm{M})$. In addition, these calluses, after being transferred to the differentiation medium, were able to form embryos, but only in the globular stage.

DPI supplied at 1,10 and $100 \mu \mathrm{M}$ in the presence of $0.5 \mu \mathrm{M} 2,4-\mathrm{D}$ caused a substantial inhibition in callus growth (Fig. 8). In the presence of $1 \mu \mathrm{M}$ of this compound, calluses appeared only in the central part of the explant, near the midrib. The mass of the formed calluses was 6.5 -fold lower compared with the mass of this tissue on the standard medium (Fig. 9). The application of DPI during the IP transcription. Bars show standard deviation. Solid and dotted lines represent the M9 and M9-10a lines, respectively. Statistical analyses, ANOVA with confidence interval 0.05 , significance between groups indicated as $*$ for $\mathrm{P} \leq 0.05$, ** for $\mathrm{P} \leq 0.01, * * *$ for $\mathrm{P} \leq 0.001$ and $* * * *$ for $\mathrm{P} \leq 0.0001$

at $1 \mu \mathrm{M}$ had no significant effect on subsequent somatic embryo production on the differentiation medium (Fig. 8). This inhibitor at higher concentrations, 10 and $100 \mu \mathrm{M}$ reduced the ability of leaf explants to produce calluses and, as a consequence, somatic embryos.

The obtained results clearly indicate that 2,4-D is required for the proper course of SE in the M. truncatula embryogenic line, but at the appropriate concentration $(0.5 \mu \mathrm{M})$ because in concentrations above $5 \mu \mathrm{M}$, it disturbs the formation of somatic embryos. Inhibition by DPI indicates that, $\mathrm{O}_{2}^{--}$produced by NADPH oxidase in the early stages of the SE seems to be necessary to initiate this process.

\section{Effect of elevated concentrations of 2,4-D and DPI during the IP on the oxidative status}

The DPI present during the induction phase and 2,4-D in elevated concentrations caused disturbances in the quality of developing callus and the resulting embryos (only at the globular stage). Thus in subsequent experiments, we checked whether these compounds at selected concentrations $(5 \mu \mathrm{M}$ 


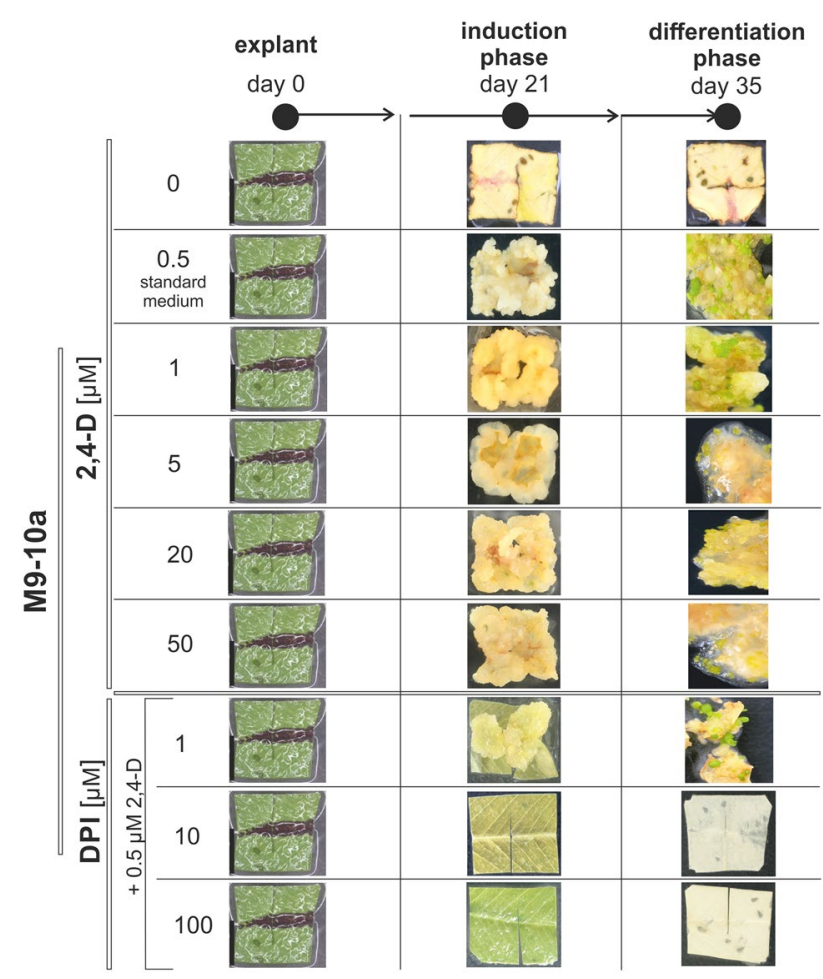

Fig. 8 Effect of 2,4-D and DPI on the ability to form callus tissue and somatic embryos in the embryogenic line (M9-10a) of Medicago truncatula

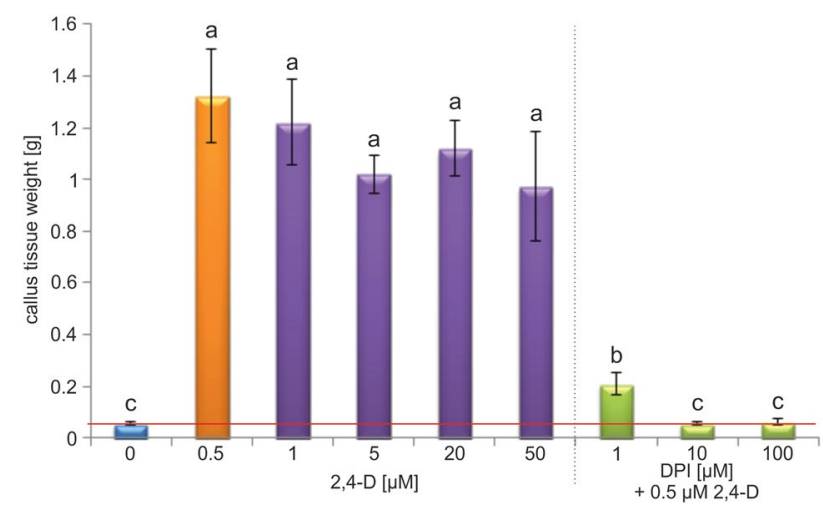

Fig. 9 Growth of the Medicago truncatula embryogenic line (M9-10a) callus after 21 days of induction on SH medium with the addition of different concentrations of 2,4-D and DPI. The red line indicates the mass of the leaf explant on day zero of the induction phase. The orange bar shows the callus mass on a standard medium

2,4-D and $10 \mu \mathrm{M}$ DPI) had an effect on the oxidative status in tissues of the M. truncatula embryogenic line (M9-10a).

In leaf explants cultured in presence of $5 \mu \mathrm{M}$ 2,4-D medium, blue formazan crystals, indicating $\mathrm{O}_{2}^{\circ-}$ accumulation, occurred over a larger area compared with explants cultured on standard medium $(0.5 \mu \mathrm{M} 2,4-\mathrm{D}$; Fig. 10). After

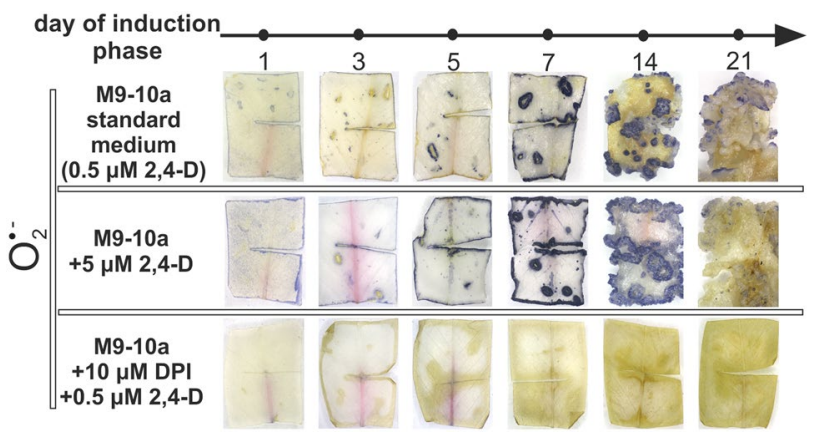

Fig. 10 Effect of 2,4-D $(5 \mu \mathrm{M})$ and DPI $(10 \mu \mathrm{M}+0.5 \mu \mathrm{M} 2,4-\mathrm{D})$ on superoxide radical content in the embryogenic line (M9-10a) of Medicago truncatula during the induction phase

the 1st day of IP, the $\mathrm{O}_{2}^{\bullet-}$ was found not only in wounds, but also in the area of the intact leaf blade. In the following days (from the 3rd to 7th days) intense blue formazan precipitates were visible only in places of wounding. After the 7th day, the callus formation was accompanied by a high accumulation of $\mathrm{O}_{2}^{\bullet-}$, which was visible both on the standard medium $(0.5 \mu \mathrm{M} 2,4-\mathrm{D})$ and much more apparently in presence of $5 \mu \mathrm{M}$ 2,4-D. $\mathrm{H}_{2} \mathrm{O}_{2}$ accumulated at wounding sites until the 7 th day of induction (brown color) in explants incubated on induction medium with $5 \mu \mathrm{M} 2,4-\mathrm{D}$, similar to what occurred on the standard medium ( $0.5 \mu \mathrm{M}$ 2,4-D; Fig. S1). After 2 and 3 weeks, $\mathrm{H}_{2} \mathrm{O}_{2}$ accumulated mainly in the formed callus. The DPI present in the medium blocked accumulation of both $\mathrm{O}_{2}^{\bullet-}$ and $\mathrm{H}_{2} \mathrm{O}_{2}$ in M. truncatula leaf explants (Fig. 10 and Fig. S1). We also checked whether the observed changes in the accumulation of the above-mentioned ROS under the influence of 2,4-D $(5 \mu \mathrm{M})$ and DPI $(10 \mu \mathrm{M})$ are related to their influence on the activity of antioxidant enzymes and expression of genes coding them during 1st week of the IP. In this experiment, the expression of only those genes that showed the greatest similarity to the enzyme activity in the embryogenic line was analyzed. When 2,4-D at $5 \mu \mathrm{M}$ was present in the induction medium, a significant nearly 2.8 fold increase in SOD activity occurred on the 1st day of induction, which was about 1.5-fold higher than in the presence of $0.5 \mu \mathrm{M}$ 2,4-D on the same day (Fig. 11a). The high level of this enzyme persisted until the 3rd day, and then reached the value observed in the primary explant. 2,4-D at $5 \mu \mathrm{M}$ caused a significant fivefold increase in transcription of gene encoding FeSOD1 on the 1st day of the IP, while on the standard medium, a tenfold increase in the expression of this gene was observed. In both cases between 1st and 3rd day, transcription of FeSODI dropped sharply (Fig. 12a). In turn after the addition of $10 \mu \mathrm{M}$ DPI to the medium, high SOD activity (a twofold increase compared with the initial explant) was observed on the 1st day of induction, then gradually decreased. Expression of FeSODI in tissues incubated 

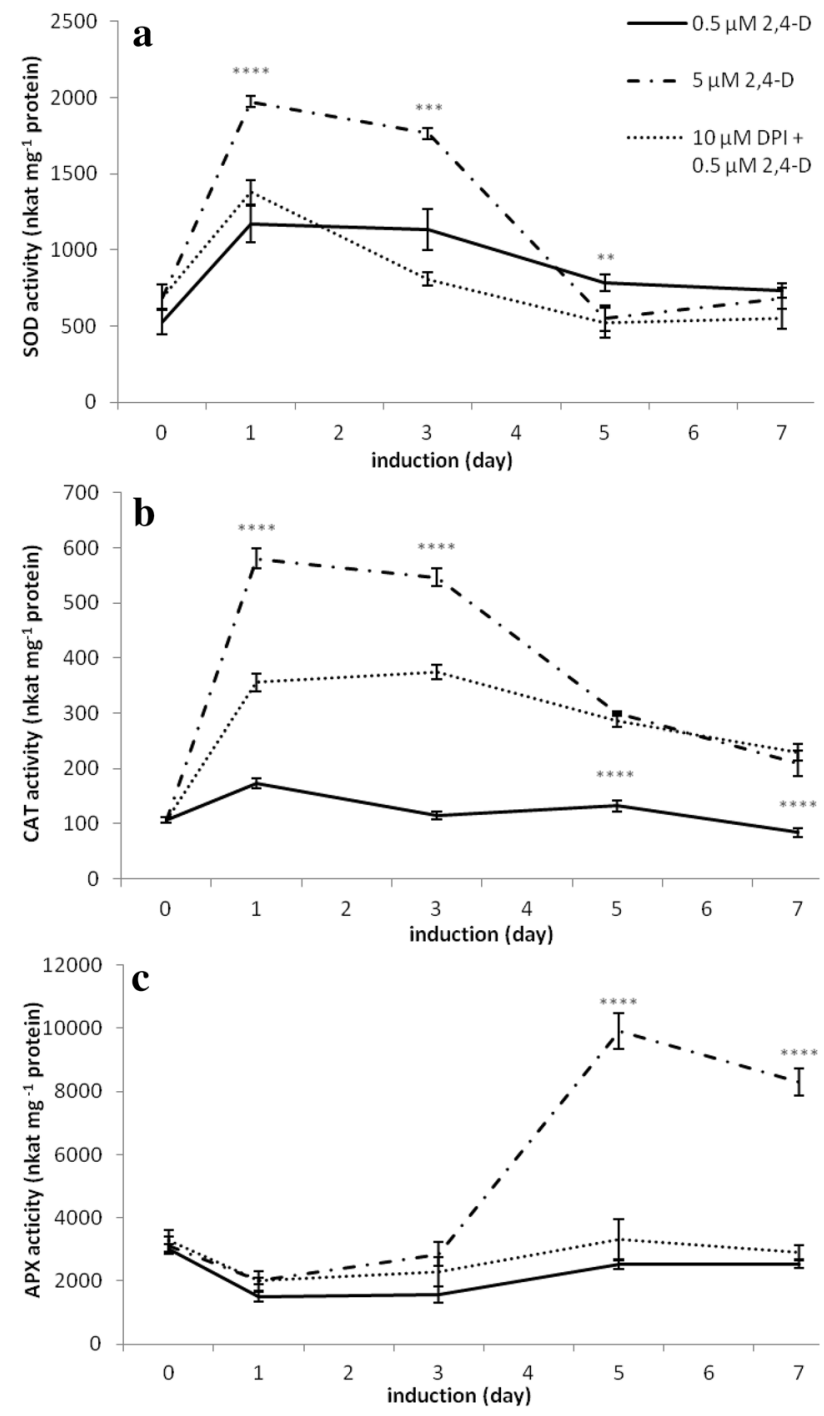

Fig. 11 Effect of 2,4-D $(0.5$ and $5 \mu \mathrm{M})$ and DPI $(10 \mu \mathrm{M}+0.5 \mu \mathrm{M} 2,4-$ D) on SOD (a), CAT (b) and APX (c) activity during the induction phase (7 days) in the embryogenic line (M9-10a) Medicago truncatula. Statistical analyses were performed using ANOVA with confidence interval 0.05 and Tukey's HSD post hoc test. Significance between groups indicated as * for $\mathrm{P} \leq 0.05$, ** for $\mathrm{P} \leq 0.01$, *** for $\mathrm{P} \leq 0.001$ and $* * * *$ for $\mathrm{P} \leq 0.0001$. Bars show standard deviation

in the presence of DPI dropped and was non-detectable from 1 st day of IP.

Similar to SOD, CAT activity from the 1 st day of the IP was significantly higher both in the presence of 2,4-D $(5 \mu \mathrm{M})$ and DPI $(10 \mu \mathrm{M})$ in comparison to the activity in the explant cultured on the standard medium (Fig. 11b). By the 7th day, a decrease in the activity of this enzyme was observed. In leaf explants cultured on induction medium containing $5 \mu \mathrm{M}$ 2,4-D, CATl expression gradually decreased to 5th day of induction (almost fourfold, Fig. 12b) and remained constant until 7th day. The dynamic of CATl expression was similar to that observed in presence of $0.5 \mu \mathrm{M}$ of 2,4-D. As with SOD, CATI expression was not detected in presence of DPI from 1st day of IP.

2,4-D at $5 \mu \mathrm{M}$ caused a significant threefold increase in APX activity between the 3rd and 5th days of induction (Fig. 11c). Of the three analyzed genes, only APX5 was characterized by changes in expression during the 1 st week of induction (Fig. 12d). The transcription level of this gene increased approximately 5.5 -fold on the $3 \mathrm{rd}$ day compared with day zero, and then decreased. In turn expression of $A P X 3$ did not change (Fig. 12c) and $A P X 6$ transcription decreased gradually to the 5th day of the IP (about a twofold decrease) and remained constant (Fig. 12e). In presence of DPI, APX activity was similar to that observed in explants cultured on the standard medium (Fig. 11c) and as with the above genes; expression was not detected (Fig. 12c-e).

This results indicate that SE disturbance in the presence of $5 \mu \mathrm{M} 2,4-\mathrm{D}$ and $10 \mu \mathrm{M}$ DPI overlapped with changes in $\mathrm{O}_{2}^{\bullet-}$ and $\mathrm{H}_{2} \mathrm{O}_{2}$ accumulation, activity of antioxidant enzymes and expression of the genes encoding them.

\section{Discussion}

It has been suggested that there is a relationship between increased production of ROS and the ability to form somatic embryos (Zavattieri et al. 2010; Rose 2019). Abiotic stress conditions (e.g., wounding, sterilization) are often together with plant growth regulators (e.g., 2,4-D), considered as one of the most important factors initiating plant somatic embryogenesis. The current results showed that in response to chemical (sterilization in sodium hypochlorite) and mechanical (wounding) stress the accumulation of ROS in leaf explants of M9 and M9-10a is at a similar level, both in the case of location and speed appearance of $\mathrm{O}_{2}^{--}$and $\mathrm{H}_{2} \mathrm{O}_{2}$. In both lines, the antioxidant enzymatic system is active; during the 1 st week of the IP, the activity of SOD increased sharply until the 1 st day, which was correlated with $\mathrm{H}_{2} \mathrm{O}_{2}$ appearing in the explants of both lines and the reduction of $\mathrm{O}_{2}^{--}$accumulation. The high FeSODI expression of all tested genes (CuZnSOD1-4, FeSOD1-2, MnSOD) on the 1st day of the IP may indicate that the FeSOD isoform participates in the first reaction of plant tissue to stress. SOD activity in the SE process has been studied in many species of plants, but those studies are mainly concerned with embryo formation. In Lycium barbarum (Kairong et al. 1999), the increase in the activity of SOD during the differentiation phase is associated with the processes of cell differentiation. It is widely known that the activity of SOD results in accumulation of $\mathrm{H}_{2} \mathrm{O}_{2}$ in 


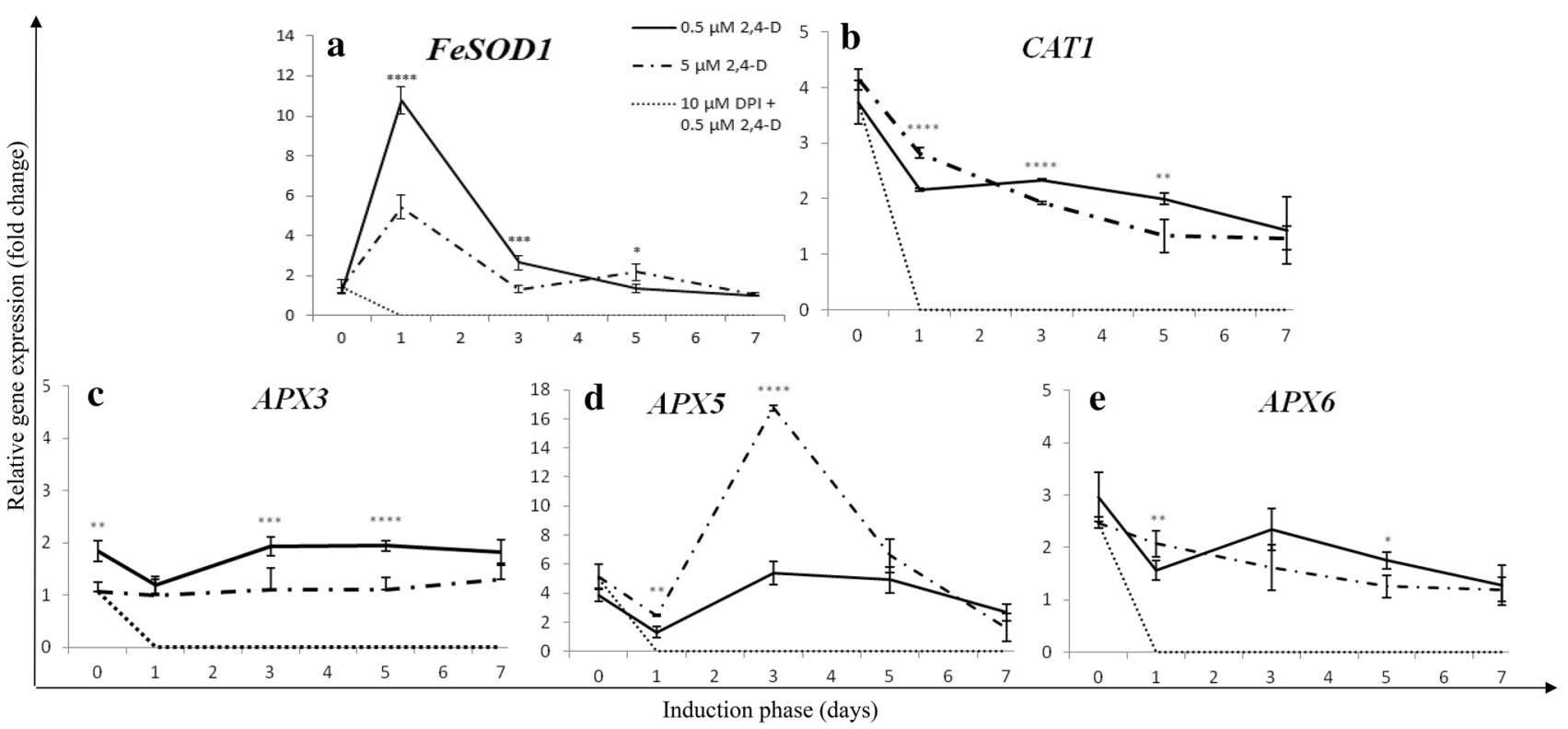

Fig. 12 Effect of 2,4-D $(0.5$ and $5 \mu \mathrm{M})$ and DPI $(10 \mu \mathrm{M}+0.5 \mu \mathrm{M} 2,4-$ D) on the expression of the MtFeSOD1 (a), MtCAT1 (b), MtAPX3 (c) MtAPX5 (d) and APX6 (e) gene during the induction phase (7 days) in the embryogenic line (M9-10a) Medicago truncatula. Gene expression was normalized to ACTIN2 and relative to the lowest observed

cells, which in subsequent stages can be converted to $\mathrm{H}_{2} \mathrm{O}$ by CAT and APX. Previously, it was found that a decrease in catalase activity and an increase in the accumulation of $\mathrm{H}_{2} \mathrm{O}_{2}$ during the differentiation phase induces the formation of somatic embryos in the Torilis japonica (Manivannan et al. 2015), Lycium barbarum (Kairong et al. 1999) and Larix leptolepis (Zhang et al. 2010). Pasternak et al. (2007) have shown that initiation of the protoplast culture of $M$. sativa is associated with a decrease in catalase activity between 36 and $96 \mathrm{~h}$, and an APX increase at $96 \mathrm{~h}$. During the IP of SE in M. truncatula, maximal activity of CAT was observed only on the 1st day in both tested lines, and in subsequent days it gradually decreased, which is probably related to the dedifferentiation of leaf cells to form callus tissue. The high expression of the CATl gene in leaf explants and the subsequent rapid decrease in its transcription was accompanied by a gradual decrease in the activity of the enzyme encoded by this gene after the 1 st day of the IP. In contrast to the activity of catalase, the enzymatic activity of APX in the M9 and M9-10a lines reached the lowest value on the 1st day of the IP, then gradually increased, which coincides with the abovementioned results of Pasternak et al. (2007). To investigate the expression of genes encoding APX during the IP, it was necessary to identify those genes in the genome of M. truncatula. The presence of two microsomal (APX3 and APX5) and cytosolic (APX1 and APX6) APX, which formed separate clades together with similar APX of the transcription. Statistical analyses were performed using ANOVA with confidence interval 0.05 and Tukey's HSD post hoc test. Significance between groups indicated as $*$ for $\mathrm{P} \leq 0.05$, ** for $\mathrm{P} \leq 0.01$, *** for $\mathrm{P} \leq 0.001$ and $* * * *$ for $\mathrm{P} \leq 0.0001$. Bars show standard deviation

Fabaceae family was confirmed. All the above-mentioned genes were expressed during the 1 st week of the IP. Three $A P X$ genes (APX3, APX5 and APX6) of four identified, had similar expression profiles. Thus, during the IP, the first line of defense against increasing accumulation of free radicals is an increase in the activity of SOD and CAT. The continuous decrease in CAT activity after the 1st day of the induction phase with a simultaneous increase in APX activity indicates that these two enzymes control the $\mathrm{H}_{2} \mathrm{O}_{2}$ level, which seems to be important for furthering the course of SE and for the formation of somatic embryos.

The above results showed that primary explants of $M$. truncatula non-embryogenic and embryogenic lines do not differ in the ability to produce ROS. Neither do they differ in their defense reaction, such as antioxidant enzyme activity and expression of genes encoding them, to mechanical and chemical stress.

Similarly to cases of other plants, 2,4-D, an herbicide with auxin-like properties, is used to induce SE in $M$. truncatula (Neves et al. 1999). However, scant information is available about it causing the formation of abnormal embryos when it is used in the induction medium at too high concentrations (Garcia et al. 2019). It was interesting to determine whether this compound changes the oxidative status in tissues during the IP. The present study confirmed that for induction of M. truncatula SE in M9-10a 2,4-D is essential at a low concentration $(0.5 \mu \mathrm{M})$; its absence in the IP resulted in the blocking of embryogenic callus formation. The presence of 
2,4-D in the induction medium at higher concentrations than 0.5 and $1 \mu \mathrm{M}$ does not inhibit, but disturbs the production of highly embryogenic callus and formation fully developed embryos; the embryos are only globular. This is probably due to the high accumulation of 2,4-D in the explant cells and further blocking of cell differentiation after transfer to a differentiating medium. Addition of 2,4-D to the induction medium in high concentrations in the culture of Glycine max (Shoemaker et al. 1991), Carya illinonensis (Rodriguez and Wetzstein 1998) and Theobroma cacao (Garcia et al. 2016) caused abnormalities in the development of embryos. 2,4-D leads to a loss of primary polarization of cells and interferes with the proper polar transport of auxins, which translates into disturbances in organogenesis (Karami et al. 2009; Karami and Saidi 2010). These disorders in the callus and embryo development in $M$. truncatula can be associated with the observed higher accumulation $\mathrm{O}_{2}^{--}$in the presence of 2,4-D at a concentration tenfold higher $(5 \mu \mathrm{M})$ than what is optimal $(0.5 \mu \mathrm{M})$. Thus the 2,4-D at an appropriately selected concentration in the induction medium stimulates the formation of embryogenic callus tissue without disturbing the further development of $M$. truncatula somatic embryos.

The presence of DPI results in the suppression of $\mathrm{O}_{2}^{\bullet-}$ and consequently $\mathrm{H}_{2} \mathrm{O}_{2}$, reducing the total ROS in plant cells (Cross and Jones 1986). In the M. truncatula culture, DPI at a concentration of $1 \mu \mathrm{M}$ limits the formation of callus tissue; it appears only along the midrib of the explants. This inhibitor present in a higher concentration $(10,100 \mu \mathrm{M})$ completely blocked the dedifferentiation of somatic cells and the formation of callus. Similar results were obtained in the Nicotiana tabacum protoplast culture, where the addition of $1 \mu \mathrm{M}$ DPI to the medium limited cell division and DPI in higher concentrations blocked this process (Lee et al. 2017). The addition of DPI to the induction medium completely inhibited $\mathrm{O}_{2}^{--}$accumulation in $M$. truncatula explants, which correlated with the inhibition of callus tissue formation.

These observed changes in ROS accumulation in the presence of 2,4-D $(5 \mu \mathrm{M})$ and DPI $(10 \mu \mathrm{M})$ results in a different level of SOD, CAT, APX activity and the expression of genes encoding them, consequently determining the ability of somatic cells to enter into the pathway of embryogenesis. In presence of 2,4-D at $5 \mu \mathrm{M}$ SOD activity increased, which may be associated with increased $\mathrm{O}_{2}^{\bullet-}$ accumulation at this time. After applying DPI, the lack of $\mathrm{O}_{2}^{\bullet-}$ and the low activity of SOD caused a reduction in the accumulation of $\mathrm{H}_{2} \mathrm{O}_{2}$, but did not change the APX activity. No expression of CAT1 in the presence of DPI was observed, although the enzyme encoded by this gene showed increased activity relative to that of day zero. In addition, in the cultures of M. truncatula and $N$. tabacum, it has been shown that the enzymatic activity of catalase does not always coincide with the level of expression of the gene encoding it (Polidoros et al. 2003; Lee et al. 2017). In the presence of $5 \mu \mathrm{M}$ 2,4-D until the 3rd day of the IP CAT activity was maintained at a higher level than in explants cultured on the standard medium. Under the same conditions, an increase in APX between the 3rd and 7th days overlapped with a decrease in CAT activity. However, in the protoplast culture of M. sativa, an increase in 2,4-D concentration from 0.1 to $10 \mu \mathrm{M}$ caused an increase in APX activity until the 1st day, which resulted in the development of proembryogenic cell clusters (Pasternak et al. 2002). In M. truncatula in presence of $5 \mu \mathrm{M}$ 2,4-D, only APX 5 showed a difference in its expression profile compared with that in the standard medium, which may indicate that only this gene undergoes transcription changes under the influence of a higher level of ROS in the cell.

In conclusion, the results of the present study indicates that response of the M. truncatula non-embryogenic and embryogenic line to chemical and mechanical stress is similar both in ROS production and in the activation of the defense reaction, despite the different capacity of these lines to form somatic embryos. These defense mechanisms involve first an increase of SOD and CAT activity and later APX. The presence of 2,4-D in low concentration $(0.5 \mu \mathrm{M})$ during induction phase (IP) is necessary for the formation of embryogenic callus and consequently for the embryo development. Higher concentrations of this herbicide causes an increase in accumulation of $\mathrm{O}_{2}^{--}$and in the activity of antioxidant enzymes, which does not block the formation of callus and somatic embryos, but limits these processes. However, the lack of 2,4-D in the induction medium inhibited cell dedifferentiation. After supplementing the induction medium with DPI, the production of callus, and as a consequence somatic embryos, was drastically reduced or blocked. Inhibition of cells dedifferentiation by DPI due to blocking the production of $\mathrm{O}_{2}^{--}$and lowering the expression of genes encoding antioxidant enzymes leading to a change in the activities of these enzymes indicates that a certain level of ROS are necessary to induce SE.

Acknowledgements The authors are very grateful to Professor Jan Kępczyński (Department of Plant Physiology and Genetic Engineering) for valuable advice during preparation of the manuscript. We are indebted to Edanz Group (Japan) for linguistic assistance.

Author contributions EK and AO conceived and designed the research. AO constructed the experiments. EK and AO analyzed the data and wrote the manuscript. EK provided the funding.

\section{Compliance with ethical standards}

Conflict of interest The authors declare that they have not conflict of interest.

Open Access This article is distributed under the terms of the Creative Commons Attribution 4.0 International License (http://creativeco mmons.org/licenses/by/4.0/), which permits unrestricted use, distribution, and reproduction in any medium, provided you give appropriate 
credit to the original author(s) and the source, provide a link to the Creative Commons license, and indicate if changes were made.

\section{References}

Aebi H (1974) Catalase. In: Bergmeyer HU (ed) Methods of enzymatic analysis. Academic Press, New York

Bradford MM (1976) A rapid and sensitive method for the quantitation of microgram quantities of protein utilizing the principle of protein-dye binding. Anal Biochem 72:248-254

Cross AR, Jones OT (1986) The effect of the inhibitor diphenylene iodonium on the superoxide-generating system of neutrophils. Specific labeling of a component polypeptide of the oxidase. Biochem J 237(1):111-116

Elhiti M, Stasolla C (2015) ROS signalling in plant embryogenesis. In: Gupta K, Igamberdiev A (eds) Reactive oxygen and nitrogen species signaling and communication in plants. Signaling and communication in plants, vol 23. Springer, Cham

Fehér A (2015) Somatic embryogenesis-stress-induced remodeling of plant cell fate. Biochim Biophys Acta 1849(4):385-402

Fryer MJ, Oxborough K, Mullineaux PM et al (2002) Imaging a photooxidative stress responses in leaves. J Exp Bot 53(372):1249-1254

Garcia C, Corręa F, Findley S et al (2016) Optimization of somatic embryogenesis procedure for commercial clones of Theobroma cacao L. Afr J Biotechnol 15:1936-1951

Garcia C, Furtado de Almeida AA, Costa M et al (2019) Abnormalities in somatic embryogenesis caused by 2,4-D: an overview. PCTOC $137: 193$

Giannopolitis CN, Ries SK (1977) Superoxide dismutase: I. Occurrence in higher plants. Plant Physiol 59(2):309-314

Grossmann K (2010) Auxin herbicides: current status of mechanism and mode of action. Pest Manag Sci 66(2):113-120

Kairong C, Gengsheng X, Xinmin L et al (1999) Effect of hydrogen peroxide on somatic embryogenesis of Lycium barbarum L. Plant Sci 146:9-16

Karami O, Saidi A (2010) The molecular basis for stress-induced acquisition of somatic embryogenesis. Mol Biol Rep 37:2493-2507

Karami O, Aghavaisi B, Pour AM (2009) Molecular aspects of somaticto-embryogenic transition in plants. J Chem Biol 2:177-190

Karuppanapandian T, Wang HW, Prabakaran N et al (2011) 2,4-Dichlorophenoxyacetic acid-induced leaf senescence in mung bean (Vigna radiata $\mathrm{L}$. Wilczek) and senescence inhibition by cotreatment with silver nanoparticles. Plant Physiol Biochem 49(2):168-177

Kearse M, Moir R, Wilson A et al (2012) Geneious basic: an integrated and extendable desktop software platform for the organization and analysis of sequence data. Bioinformatics 28(12):1647-1649

Lee DJ, Choi HJ, Moon ME et al (2017) Superoxide serves as a putative signal molecule for plant cell division: overexpression of CaRLK1 promotes the plant cell cycle via accumulation of $\mathrm{O}_{2}{ }^{-}$ and decrease in $\mathrm{H}_{2} \mathrm{O}_{2}$. Physiol Plant 159(2):228-243

Manivannan A, Jana S, Soundararajan P et al (2015) Antioxidant enzymes metabolism and cellular differentiation during the developmental stages of somatic embryogenesis in Torilis japonica (Houtt.) DC. POJ 8(5):461-471

Murashige T, Skoog F (1962) A revised medium for rapid growth and bio assays with tobacco tissue cultures. Physiol Plant 15(3):473-497

Nakano Y, Asada K (1981) Hydrogen peroxide is scavenged by ascorbate-specific peroxidase in spinach chloroplasts. Plant Cell Physiol 22(5):867-880

Neves LO, Duque SRL, Almeida JS, Fevereiro PS (1999) Repetitive somatic embryogenesis in Medicago truncatula ssp.
Narbonensis and M. truncatula Gaertn cv. Jemolong. Plant Cell Rep 18:398-405

Nolan KE, Rose RJ, Gorst JR (1989) Regeneration of Medicago truncatula from tissue culture: increased somatic embryogenesis using explants from regenerated plants. Plant Cell Rep 8:278-281

Nolan EK, Saeed NA, Rose RJ (2006) The stress kinase gene MtSK1 in Medicago truncatula with particular reference to somatic embryogenesis. Plant Cell Rep 25:711-722

Orłowska A, Kępczyńska E (2018) Identification of Polycomb Repressive Complex1, Trithorax group genes and their simultaneous expression with WUSCHEL, WUSCHEL-related Homeobox 5 and SHOOT MERISTEMLESS during the induction phase of somatic embryogenesis in Medicago truncatula Gaertn. PCTOC. https:// doi.org/10.1007/s11240-018-1425-6

Orłowska A, Igielski R, Łagowska K et al (2017) Identification of LEC1, L1L and Polycomb Repressive Complex 2 genes and their expression during the induction phase of Medicago truncatula Gaertn. somatic embryogenesis. PCTOC. https://doi.org/10.1007/ s11240-016-1161-8

Pasternak TP, Prinsen E, Ayaydin F et al (2002) The role of auxin, pH, and stress in the activation of embryogenic cell division in leaf protoplast-derived cells of alfalfa. Plant Physiol 129(4):1807-1819

Pasternak TP, Ötvös K, Domoki M et al (2007) Linked activation of cell division and oxidative stress defense in alfalfa leaf protoplastderived cells in dependent on exogenous auxin. Plant Growth Regul 51:109-117

Polidoros AN, Mylona PV, Pasentsis K et al (2003) Catalase expression in normal metabolism and under stress in the model legume Medicago truncatula. XII International Congress on "Genes, Gene families and isozymes", Berlin, p 147-156

Rodriguez APM, Wetzstein HY (1998) A morphological and histological comparison of the initiation and development of pecan (Carya illinoinensis) somatic embryogenic cultures induced with naphthaleneacetic acid or 2,4-dichlorophenoxyacetic acid. Protoplasma 204:71

Romero-Puertas MC, McCarthy I, Gómez M et al (2004) Reactive oxygen species-mediated enzymatic systems involved in the oxidative action of 2,4-dichlotophenoxyacetic acid. Plant Cell Environ 27:1135-1148

Rose RJ (2019) Somatic embryogenesis in the Medicago truncatula model: cellular and molecular mechanisms. Front Plant Sci 10:267

Rose JR, Sheahen MB, Tiew TW-Y (2013) Connecting stress to development in the induction of somatic embryogenesis. In: Aslam J, Srivastava PS, Sharma MP (eds) Somatic embryogenesis and gene expression. Narosa Publishing House, New Delhi, pp 146-156

Ruduś I, Weiler EW, Kępczyńska E (2009) Do stress-related phytohormones, abscisic acid and jasmonic acid play a role in the regulation of Medicago sativa L. somatic embryogenesis? Plant Growth Regul 59:159

Schenk RU, Hildebrandt AC (1972) Medium and techniques for induction and growth of monocotyledonous and dicotyledonous plant cell cultures. Can J Botany 50(1):199-204

Shoemaker RC, Amberger LA, Palmer RG et al (1991) Effect of 2,4-dichlorophenoxyacetic acid concentration on somatic embryogenesis and heritable variation in soybean [Glycine $\max (\mathrm{L})$ Merr.]. Vitro Cell Dev Biol Plant 27:84-88

Song J, Zeng L, Chen R et al (2018) In silico identification and expression analysis of superoxide dismutase (SOD) gene family in Medicago truncatula. 3 Biotech 8:348

Thordal-Christensen H, Zhang Z, Wei Y et al (1997) Subcellular localization of $\mathrm{H}_{2} \mathrm{O}_{2}$ in plants. $\mathrm{H}_{2} \mathrm{O}_{2}$ accumulation in papillae and hypersensitive response during the barley-powdery mildew interaction. Plant J 11(6): 1187-1194

Zavattieri MA, Frederico AM, Lima M et al (2010) Induction of somatic embryogenesis as an example of stress-related plant 
reactions. Electron J Biotechnol. https://doi.org/10.2225/vol13 -issue1-fulltext-4

Zhang S, Han S, Yang W et al (2010) Changes in $\mathrm{H}_{2} \mathrm{O}_{2}$ content and antioxidant enzyme gene expression during the somatic embryogenesis of Larix leptolepis. PCTOC 100:21-29
Publisher's Note Springer Nature remains neutral with regard to jurisdictional claims in published maps and institutional affiliations. 